\section{Coincident cytomegalovirus infection and toxoplasmosis in an uncompromised host}

Simultaneous infection by the obligate intracellular parasite Toxoplasma gondii and by cytomegalovirus has been described in stillborn infants with congenitally acquired disease ${ }^{12}$ and occurs with an unexpected frequency in patients with disseminated neoplasia. ${ }^{34}$ Under normal circumstances it is uncommon for either agent to cause overt disease, and coincident infection with $T$ gondii and cytomegalovirus does not appear to have been described in an otherwise healthy adult. I present a case of atypical mononucleosis accompanied by serological evidence of infection with both agents.

\section{Case report}

A 71-year-old Welsh hill farmer was admitted three weeks after the onset of chills, lassitude, anorexia, occasional vomiting, and episodes of irrational behaviour. Apart from fever of $38^{\circ} \mathrm{C}$ there were no abnormal physical signs. Haemoglobin concentration was $13.8 \mathrm{~g} / \mathrm{dl}$ with normal blood variables. Serum sodium and potassium concentrations were low at $131 \mathrm{mmol}(\mathrm{mEq}) / 1$ and $3.32 \mathrm{mmol}(\mathrm{mEq}) / 1$ respectively; urea concentration was $9.4 \mathrm{mmol} / 1$ $(56.4 \mathrm{mg} / 100 \mathrm{ml}$ ) and aspartate transaminase activity $46 \mathrm{IU} / 1$ (normal 10-35 IU/1). Serum proteins and bilirubin concentrations and alkaline phosphatase activity were normal, and urine analysis and chest radiography showed no abnormalities. He remained feverish and became confused, enfeebled, and incontinent of urine. Further tests indicated inappropriate secretion of antidiuretic hormone and he became increasingly withdrawn. Ten days after admission he had fine inspiratory crepitations in both upper zones, absent knee and ankle reflexes, and extensor plantar responses and had lost $5 \mathrm{~kg}$ in weight. Lumbar puncture showed normal cerebrospinal fluid. Erythrocyte sedimentation rate was $62 \mathrm{~mm}$ in the first hour; white cell count was $15.5 \times 10^{9} / 1$ with $57 \%$ polymorphs and $40 \%$ lymphocytes, and atypical lymphocytes and myelocytes were seen on the film. A PaulBunnell test result was negative, and a sternal marrow aspirate suggested a myelomonocytic leukaemia. Results of liver function tests showed a further rise in aspartate transaminase activity to $56 \mathrm{IU} / \mathrm{l}$, a bilirubin concentration of $16 \mu \mathrm{mol} / 1(0.93 \mathrm{mg} / 100 \mathrm{ml}$ ) (normal $1-15 \mu \mathrm{mol} / 1 ; 0.05-0.87 \mathrm{mg} / 100 \mathrm{ml}$ ), and an alkaline phosphatase activity of 16.2 KAU (normal 4-13 KAU). An ultrasound scan of the liver was normal, a liver biopsy specimen showed a mild non-specific hepatitis, and an iliac trephine biopsy specimen no evidence of malignancy.

The cytomegalovirus complement fixation test showed a 64 -fold rise in antibody titre from $1 / 16$ to $1 / 1024$, and the titre of cytomegalovirus $\operatorname{IgM}$ rose from $<1 / 4$ to $1 / 128$. This was accompanied by an eightfold rise of antibody in the toxoplasma dye test from $1 / 128$ to $1 / 1024$, and the titre of toxoplasma IgM rose from $<1 / 4$ to $1 / 32$. A search for other infections gave negative results.

The fever remitted two weeks after admission, but he remained unwell and was given a 10-day course of co-trimoxazole followed by $1 \mathrm{~g}$ sulphadiazine four times daily on confirmation of the diagnosis of toxoplasmosis. He began to improve after two weeks of treatment. Several months later he returned to his farming activities, and he remained well 12 months after discharge.

\section{Comment}

The nature of the infections in this patient, suggested by the atypical mononucleosis and a negative Paul-Bunnell test, were confirmed by finding a 64 -fold rise in the serum complement fixation titre to cytomegalovirus, an eightfold rise in antibody in the toxoplasma dye test, and appreciable rises in the $\operatorname{IgM}$ titres to both cytomegalovirus and $T$ gondii. Toxoplasmosis and cytomegalovirus infection may be impossible to distinguish clinically, and the high incidence of subclinical infections caused by these pathogens suggests that concurrent infections occur more often than has hitherto been recognised. Although unproved by controlled clinical trials in man, a combination of pyrimethamine and sulphonamides seems to be effective in the treatment of toxoplasmosis, especially in immunocompromised patients in whom the diagnosis is established promptly. ${ }^{45}$ Thus it is important to remember that concurrent infections may occur, as in the present case, and that a proved viral infection does not exclude the possibility of an associated treatable infection with $T$ gondii.

I gratefully acknowledge the helpful advice of Dr J M Gumpel, under whose care the patient was admitted, and Dr P J Sanderson, Northwick
Park Hospital; Professor H Stern, department of virology St George's Hospital; and Dr D G Fleck, public health laboratory, St George's Hospital, in whose laboratories the serological studies were performed.

${ }^{1}$ Demian SDE, Donnelly WH, Monif GRG. Coexistent congenital cytomegalovirus and toxoplasmosis in a stillborn. Am $\mathcal{F}$ Dis Child 1973; $125: 420-1$.

2 Sotelo-Avila C, Perry CM, Parvey LS, Eyal FG. Clinicopathologic conference: coexistent congenital cytomegalovirus and toxoplasmosis in a newborn infant. $\mathcal{F}$ Tenn Med Assoc 1974;67:588-92.

${ }^{3}$ Luna MA, Lichtiger B. Disseminated toxoplasmosis and cytomegalovirus infection complicating Hodgkin's disease. Am 7 Clin Pathol 1971 ;55: 499-505.

4ietzke WM, Gelderman AH, Grimley PM, Valsamis MP. Toxoplasmosis complicating malignancy. Cancer 1968;21:816-27.

5 Beverley JKA. Toxoplasmosis. Br Med f 1973;i:475-8.

(Accepted 8 April 1981)

Northwick Park Hospital and MRC Division of Communicable

Disease, Clinical Research Centre, Harrow HA1 3UJ

KARL G NICHOLSON, MB, MRCP, honorary senior medical registrar

\section{Management of patients after mastectomy}

Cochrane $e t a l^{1}$ questioned the value of routine follow-up at hospital clinics for patients who had undergone resection of the large bowel for malignant disease. They suggested that the time spent in following up these cases might be more usefully spent in educating the patient about symptoms that might arise after the operation.

The management of patients with other malignant disease is also worthy of review. This study attempts to show that patients who have had a mastectomy are more likely to present with the symptoms of recurrence to their general practitioner than to have the recurrence detected at the hospital follow-up clinic.

\section{Method and results}

All patients who had had a mastectomy for carcinoma of the breast in Hereford County Hospital during 1973-5 were identified from the hospital activity analysis file. Their records were examined and those who had been recorded as developing a recurrence of the carcinoma while still under the supervision of the surgeon were included in the study. Some patients were found to have had recurrent disease but to have been discharged from the clinic either because of their age or because they lived a long way from the hospital. These were not included in the study.

During the three years studied 150 women were recorded as having had a mastectomy. The notes of 124 patients were reviewed; the remaining 26 could not be traced. Fifty-one women were found to have had a recurrence of the carcinoma after mastectomy and while still under the supervision of the surgeon. Of these, $17(33 \%)$ had been found to have the recurrence at routine follow-up, $32(63 \%)$ had presented with the symptoms of the recurrence to their general practitioner, and two $(4 \%)$ had presented with a pathological fracture.

\section{Comment}

The reasons for the routine follow-up of patients who have had a mastectomy for carcinoma of the breast are to detect curable recurrent disease and to provide early palliation of incurable recurrences. The treatment of postoperative complications may also be dealt with, and a prosthesis provided.

In most cases prolonged routine follow-up appears to be of limited value as far as the detection of recurrent disease is concerned, as patients with a recurrence are more likely to present to the general practitioner with symptoms. If this is so, perhaps the management of this problem might be dealt with more appropriately by the general practitioner rather than the surgeon.

There is also some evidence that a few patients delay reporting important symptoms because they are due to attend the hospital for 
their routine follow-up at some time in the near future. One patient in the study was noted as having had symptoms for two months before her recurrent disease was detected at a routine attendance. She had not reported these symptoms because she was prepared to wait until she attended the clinic.

Most general practitioners are aware that their patients are often unhappy with their routine consultations in the surgical outpatient department. Not only are the hospital waiting rooms overcrowded but also the consultation is usually cursory and is often undertaken by the most junior member of the hospital team. The examining doctor may never have seen the patient before, and it is not uncommon for a patient to be given conflicting advice on consecutive visits because she has been seen by different doctors.

The resources of our health service are finite, and if our figures are representative of the UK as a whole then the time of the surgical team might be more usefully spent elsewhere.

We thank the surgeons and the staff of the records department of the County Hospital, Hereford, for their help.

${ }^{1}$ Cochrane JPS, Williams JT, Faber RG, Slack WW. Value of outpatient follow-up after curative surgery for carcinoma of the large bowel. $\mathrm{Br}$ Med f 1980;280:593-5.

(Accepted 30 March 1981)

\section{Much Birch, Hereford}

P B CLARK, MB, MRCGP, general practitioner

County Hospital, Hereford

D L MORRIS, MB, FRCS, surgical registrar

\section{Red cell indices and iron stores in patients undergoing haemodialysis}

Serum ferritin concentrations correlate well with iron stores in patients with chronic renal failure. ${ }^{12}$ It has been suggested that the red cell indices, mean cell haemoglobin $(\mathrm{MCH})$ and volume $(\mathrm{MCV})$, are also correlated with serum ferritin concentrations. ${ }^{4} \mathrm{MCH}$ and $\mathrm{MCV}$ are easier to measure than the serum ferritin concentration and therefore we have examined their value in detecting lack of iron and predicting response to iron treatment in patients undergoing haemodialysis.

\section{Patients, methods, and results}

A total of 131 patients ( 82 men, 49 women) either training for or undergoing home haemodialysis were studied. Their mean age was 44.6 years (raige 14-68) and the mean time on dialysis 42 months (range $<1-152$ ). The patients underwent dialysis for 10 hours twice weekly using Meltec Maxi multipoint dialysers (surface area $1.0 \mathrm{~m}^{2}$ ). Other details of management are published elsewhere. ${ }^{3}$ Serum ferritin concentration was measured using a radioimmunoassay method (GammaDab, Clinical Assays). The normal ranges were : men $25-150 \mu \mathrm{g} / \mathrm{l}$, women $15-80 \mu \mathrm{g} / 1$; and values in iron deficiency anaemia were $<10 \mu \mathrm{g} / \mathrm{l}$. An excellent correlation was shown between serum ferritin concentration and bone marrow stainable iron in 32 of our patients. Haemoglobin concentration, $\mathrm{MCV}$, and $\mathrm{MCH}$ were determined using a Coulter $S$ counter. All values for serum ferritin were log transformed for statistical analysis.

In the whole population the mean value for $\mathrm{MCH}$ was $29.8 \mathrm{pg}$ (range 19.3 to 36.9) and for MCV $91 \mathrm{fl}$ (range 65-107). There was a significant correlation between $\mathrm{MCH}$ and serum ferritin concentration $(r=0.550, n=131, p=$ $<0.001$; regression equation-log ferritin $=0.121 \mathrm{MCH}-1 \cdot 288$ ). The relation between $\mathrm{MCV}$ and serum ferritin concentration was similar ( $\mathbf{r}=$ $0.529, \mathrm{n}=131, \mathrm{p}<0.001$; regression equation-log ferritin $=0.046 \mathrm{MCV}-$ 1.854).

The change in haemoglobin concentration after parenteral iron treatment with 1-1.5 g of iron dextran was monitored in 31 patients with stable haemoglobin concentrations. They received no blood transfusions and suffered no extraordinary blood loss during the study. An increase in haemoglobin concentration of at least $1 \mathrm{~g} / \mathrm{dl}$, measured four to six weeks after treatment and sustained thereafter, was regarded as an indication of response to iron. A mean increase in haemoglobin concentration of $2.5 \mathrm{~g} / \mathrm{dl}$ (range 1.0-4.2) occurred in 18 patients. The association between MCH-MCV and serum ferritin concentration in the treated patients $(r=0.616$ and $r=0.568$; $p<0.001$ respectively) was similar to that observed in the entire population under study. The relations between serum ferritin concentration and pretreatment $\mathrm{MCH}$ and $\mathrm{MCV}$ in the patients receiving parenteral iron treatment are shown in the figure.
- Patients who responded to treatment - - Serum ferritin concentration of $55 \mu \mathrm{g} / 1$ Normal range for red cell indices
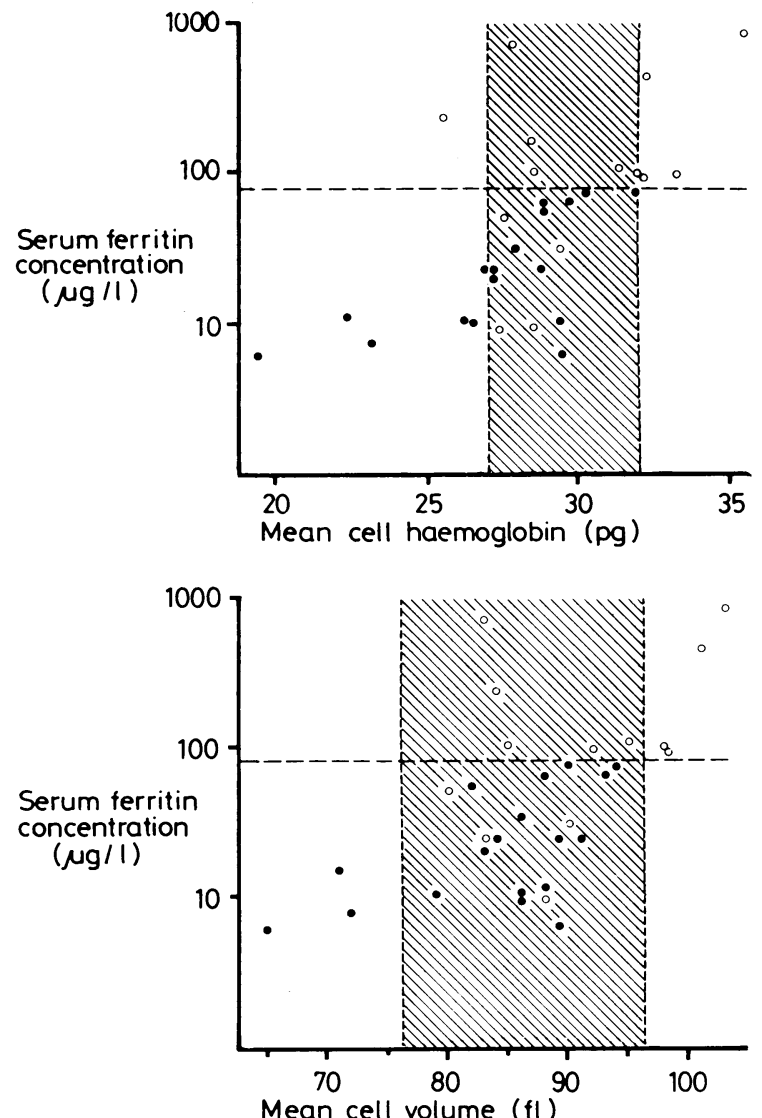

Relation between serum ferritin concentration and pretreatment $\mathrm{MCH}$ and $\mathrm{MCV}$ values in 31 patients receiving parenteral iron treatment.

\section{Comment}

Both $\mathrm{MCH}$ and $\mathrm{MCV}$ are positively correlated with serum ferritin concentration, and hence with iron stores, as has been previously shown. ${ }^{4}$ We showed earlier ${ }^{3}$ that iron treatment was likely to increase haemoglobin concentration $(>1 \mathrm{~g} / \mathrm{dl})$ in patients undergoing haemodialysis with serum ferritin concentrations of up to $55 \mu \mathrm{g} / \mathrm{l}$. The data presented here indicate that low MCH or MCV values may be used to confirm iron deficiency. Of the 18 patients who responded to iron treatment, however, 12 had $\mathrm{MCH}$ concentrations and $15 \mathrm{MCV}$ concentrations within the respective normal ranges. Therefore neither $\mathrm{MCH}$ nor $\mathrm{MCV}$ is a reliable indicator of iron deficiency or of response to iron treatment in patients undergoing haemodialysis.

${ }^{1}$ Hussein S, Prieto J, O'Shea M, Hoffbrand AV, Baillod RA, Moorhead JF. Serum ferritin assay and iron status in chronic renal failure and haemodialysis. $\mathrm{Br}$ Med $\mathcal{f} 1975$; i :546-8.

2 Beallo R, Dallman PR, Schoenfeld PY, Humphreys MH. Serum ferritin and iron deficiency in patients on chronic haemodialysis. Trans Am Soc Artif Intern Organs 1976;22:73-9.

${ }^{3}$ Lynn KL, Mitchell TR, Shepperd J. Serum ferritin concentration in patients receiving maintenance haemodialysis. Clin Nephrol 1980;14: 124-7.

4 Gokal R, Millard PR, Weatherall DJ, Callender STE, Ledingham JGG, Oliver DO. Iron metabolism in haemodialysis patients. A study of the management of iron therapy and overload. $Q \mathcal{F} \mathrm{Med} 1979 ; 48: 369-91$.

(Accepted 13 March 1981)

Departments of Medicine and Haematology, Charing Cross Hospital Medical School, London W6 8RF

K L LYNN, FRACP, senior registrar in medicine (present appointment: nephrologist, department of nephrology, Christchurch Hospital, Christchurch 1, New Zealand)

T R MITCHELL, MRCPATH, senior lecturer in haematology

J SHEPPERD, FILMS, chief medical laboratory scientific officer 